\title{
ISOLATION AND GROWTH OF DINOFLAGELLATE, Scrippsiella sp. AND DIATOM, Melosira cf. moniliformis IN CONTROLLED CONDITIONS
}

\author{
Wa lba\# \\ Fisheries, Aquaculture and Veterinary Sciences, University of Rhode Island (URI)
}

(Received 5 December 2013; Accepted 8 May 2014)

\begin{abstract}
The growth of the dinoflagellate, Scrippsiella sp. from Narragansett Bay, USA and the chain-forming benthic diatom, Melosira cf. moniliformis from Kendari Bay, Indonesia was evaluated under optimized laboratory conditions to investigate potential new candidates for shrimp aquaculture hatchery feeds. Isolation of microalgae was performed using capillary pipets in f/8- Si for Scrippsiella sp. and f/2 for M. cf. moniliformis. Isolated cells were placed in an incubator with a photoperiod of 12:12 hour (light: dark cycle), at light intensities of 62-89 $\mu \mathrm{mol}$ photons. $\mathrm{m}^{-2}$.s and at temperature of $20^{\circ} \mathrm{C}$. Microalgae cells were cultured in $150-\mathrm{mL}$ Erlenmeyer flasks containing $100 \mathrm{~mL}$ of $\mathrm{f} / 2-\mathrm{Si}$ medium for Scrippsiella spin triplicates and in $50-\mathrm{mL}$ culture tubes containing $20 \mathrm{~mL}$ of $\mathrm{f} / 2$ medium for $\mathrm{M}$. cf. moniliformis in four replicates. The cells in culture flasks were used in cell counting experiments while those in tubes were for fluorometer trials. Growth evaluation was conducted every 2- 3 days. The diatom, M. cf. moniliformis was in logarithmic phase when observed at 2 to 7 days after inoculation and showed a high growth rate $\left(\mu=0.52\right.$ day $\left.^{-1}\right)$ and high division rate $\left(\mathrm{k}=0.76\right.$ day $^{-1}, 1$ division every 1.3 days). Logarithmic phase of Scrippsiella in culture flasks was started on day 7 to $30\left(\mu=0.17\right.$ day $^{-1}$ and $k=0.25$ day ${ }^{-1}$ or 1 division every 4 days). In culture tubes, Scrippsiella sp. reached logarithmic phase at day 21 to 47 ( $\mu=0.12$ day $^{-1}$ and $k=0.18$ day $^{-1}, 1$ division every 5.65 days). This study indicates that $\mathrm{M}$. cf. moniliformis can be used for aquaculture hatcheries feed but further study for the nutrition composition is needed. Scrippsiella sp. is potentially toxic for aquaculture at high densities, therefore they should be assessed carefully if used for aquaculture feeds.
\end{abstract}

KEYWORDS: white shrimp, microalga, Scrippsiella sp. and Melosira cf. monoliformis

\section{INTRODUCTION}

Microalgae have been grown worldwide for several industrial purposes such as biofuel, pharmaceuticals, and aquaculture. They can be grown from starter cultures provided by microalgae research centers or commercial hatcheries such as The Commonwealth Scien- tific and Industrial Research Organization (CSIRO) in Australia (Martinez- Fernandez, 2007), Milford Laboratory in United States (US) (Wikfors $\&$ Ohno, 2001), The Culture Collection for Algae and Protozoa (CCAP) in Scotland and Research Centre for Oceanography, in Indonesia or alternatively, they can be isolated from natural ecosystems. For most industrial appli-

\# Corresponding author. University of Rhode Island (URI)

12 Woodward, Hall URI Main Campus, Kingston 02881, Rhode Island, USA

E-mail: wa_iba@my.uri.edu 
cations, microalgae are obtained directly from commercial providers but for research, it can be both. The choice whether to purchase or to isolate microalgae species will depend on the purpose of the studies. Most biofuel and aquaculture studies are conducted using starter cultures of known species (Avila- Villa et al., 2011; Nurachman et al., 2012; RohaniGhadikolai et al., 2012) but for other studies with the purpose of finding new candidates for industrial applications, isolating microalgae from natural waters is more common, and appropriate (Ponomarenko et al., 2009; Carboni et al., 2012).

In aquaculture, microalgae production is mainly intended as live feeds for mollusks, shrimp, and fish culture (Wikfors \& Ohno, 2001; Martinez- Fernandez \& Southgate, 2007; Kent et al., 2011). Microalgae production for aquaculture is considered to be more sustainable compared to other fish feed production (Taelman et al., 2013). Based on life cycle analysis on microalgae production for aquaculture, Taelman et al. (2013) identified recycling of nutrients and savings on energy use as important ways to increase the sustainability of algae production. Upscaling, reactor design improvements, enhancement of photosynthetic yield and a good choice of location also contributed to a low resource, and carbon footprint. To date, the use of microalgae in aquaculture hatcheries cannot be replaced fully with other types of artificial feed, such as microbound diets, and other enrichment diets (e.g., Nutrokol, S. presso and Algamac) (Galardo et al., 2002; Sanchez et al., 2012; Ma \& Qin, 2012).

Local microalgae isolates from Southeast (SE)- Sulawesi are not yet utilized despite their potential to support aquaculture industries in the region with comparable growth rate and nutritional values from imported counterparts. Currently, shrimp aquaculture in SE- Sulawesi relies on the microalgae supply from South Sulawesi and Java regions that impose high operational costs to aquaculture farms and hatcheries in the region. Importing microalgae from other regions also increases greenhouse gas (GHG) emissions due to transportation (Edwards- Jones, 2010). To reduce both this cost and GHG emissions, the use of locally-isolated, cultured microalgae for local hatchery may be considered. Local culture microalgae with good growth and complete nutritional profiles will help small holder farmers to increase the productivity of their farms and thus their incomes and at the same time may decrease the shrimp market price. Finally, small- scale and local installations of microalgae culture are promising solutions not only to overcome these problems, but these will also provide employment that can drive the economic growth of SE-Sulawesi and Indonesia in general.

The present study is investigating the growth of local microalgae isolates from Kendari Bay, SE- Sulawesi and from Narragansett Bay, Rhode Island as a preliminary approach to find good candidates of microalgae to be used in shrimp aquaculture industries in SE- Sulawesi and Indonesia in general.

\section{MATERIALS AND METHODS}

\section{Microalgae Isolation}

Microalgae samples were obtained from Narragansett Bay, Rhode Island, US (41 34.2N, 71 23.4W) and Kendari Bay, SE- Sulawesi, Indonesia ( $\left.3^{\circ} 58^{\prime} S, 122^{\circ} 35^{\prime} E\right)$. Samples from Narragansett Bay were used as a comparison species. Samples from Kendari Bay were collected using a $50 \mu \mathrm{m}$ plankton net whereas a $25 \mu \mathrm{m}$ net was used for samples from Narragansett Bay. Salinity and temperature of each sampling location were also measured.

Isolation of microalgae was performed using capillary/micro pipets as described by Andersen (2011). Pasteur pipets were heated until they could be stretched to form thin capillary pipets. Microalgae samples were observed under a dissecting microscope and designated cells for growth experiment were collected using those pipets. The cells isolated from Narragansett Bay were rinsed three times in $\mathrm{f} / 8$ medium before being placed into microtubes containing $f / 8$ medium. Samples from Kendari Bay were isolated in $\mathrm{f} / 2+\mathrm{Si}$ as they contain some chains of diatoms. The addition of Si in culture media is necessary for the formation of bio silica cell wall of diatoms (Kroger et al., 1999; Ponomorenko et al., 2004; Sumper \& Bunner, 2006; Schwenk et al., 2013).

Isolated cells were placed in an incubator (Precision Scientific Serial 9504-004) with a 12:12 hour light: dark cycle, at light intensities of $62-89 \mu \mathrm{mol}$ photons. $\mathrm{m}^{-2} \cdot \mathrm{s}^{-1}$ and at a temperature of $20^{\circ} \mathrm{C}$. Successful isolates that showed good growth with viable cells were transferred to the starter culture tubes con- 
taining $8 \mathrm{~mL}$ of $\mathrm{f} / 2$ medium for diatom species. The isolates were observed under microscope and were identified using a microalgae identification book (Hasle et al., 1997). To determine the health of the starter cultures, the culture tubes were observed under microscope after 1 week and again after 2 weeks to promote the growth. Healthy cultured cells were transferred to larger culture tubes for growth trial experiment. $4.2 \mathrm{~mL}$ of Scrippsiella sp. from the starter culture were transferred into 250- $\mathrm{mL}$ erlenmeyer flask containing $250 \mathrm{~mL}$ f/ 2- Si medium. For M. cf. moniliformis, $5 \mathrm{~mL}$ of isolates were transferred into $250 \mathrm{~mL}$ erlenmeyer flasks containing $250 \mathrm{~mL}$ of $\mathrm{f} / 2$ medium. Those cells were then transferred equally into $150 \mathrm{~mL}$ erlenmeyer flasks containing $100 \mathrm{~mL}$ of medium in triplicates and $50 \mathrm{~mL}$ culture tubes containing $20 \mathrm{~mL}$ of medium in four replicates. Flasks and tubes for growth experiment were kept in incubator under the same conditions as those of the starter cultures. The cells in culture flasks were used in cell counting experiments whereas those in tubes were for fluorometer trials.

\section{Growth Experiment}

Evaluation of growth in culture tubes from each species was conducted using a fluorometer (10- AU fluorometer, Turner Designs Sunnyvale California, USA); the interval between readings was 2-3 days. Sample cells from flasks were collected on the same day as the fluorometer reading for counting purposes. Cell counting for Scrippsiella sp. was conducted in triplicates using Sedgwick-Rafter, PalmerMaloney and Fuchs- Rosenthal slides, respectively, following the increase number of cells. Fluorometer measurements and slide counting were terminated after the cells reached stationary phase. Finally, specific growth $(\mu)$, division rate $(k)$, and division/doubling time $(T)$ during logarithmic phase for each species were calculated based on both fluorometer readings and cell counts according to formula proposed by Guillard (1973) (Wood et al., 2005) as follows:

$$
\begin{gathered}
\mu=\frac{\ln (\mathrm{N} 1 / \mathrm{No})}{\mathrm{T} 1-\mathrm{To}} \\
\mathrm{k}=\frac{\mu}{\ln 2(0.6931)} \\
T=\frac{1}{k}
\end{gathered}
$$

where:

$\mathrm{N} 1$ = Number of cells/fluorescence relative unit (rfu) at T1

No $=$ Number of cells/fluorescence relative unit (rfu) at To

$\mathrm{T} 1$ = Observation after To

To $=$ Initial observation

\section{Statistical Analysis}

Simple linear regressions were calculated using R statistic software. Data for this analysis were taken from exponential phase of growth/logarithmic phase for each species subjected to growth experiment.

\section{RESULTS AND DISCUSSION}

Two species were successfully isolated during this experiment. They were Scrippsiella sp. from Narragansett Bay and M. cf. moniliformis from Kendari Bay. Scrippsiella sp. particularly Scrippsiella trochoidea is a solitary dinoflagellate listed as a potentially harmful algal bloom forming species due to its ability to reach very high densities particularly in stratified water bodies (Attaran-Fariman \& Bloch, 2012).

Scrippsiella sp. is characterized by a violin-type shape with a pronounced girdle. It is an armored cell, brown in colour, and the chloroplasts are yellow. M. cf. moniliformis is a fast growing chain-forming diatom that commonly inhabits the estuaries or littoral zone (Majewaska et al., 2012). The cells isolated in this study resemble $M$. moniliformis in which cells are pill-shaped, from roughly cylindrical to almost spherical, and were connected in chains by mucous pads (Horner, 2002). Because of the difference in growth performance, Scrippsiella sp. was observed for 75 days by fluorometry while Melosira was observed for only 38 days. Cell counting for Scrippsiella sp. was conducted for 43 days. However M. cf. moniliformis could not be counted due to clumped cells in chains that were difficult to separate.

\section{Scrippsiella sp.}

Currently, there are 40 species of Scrippsiella in the algae data base but only 27 have been accepted taxonomically (Guiry, 2013). Taxonomic classification for Scrippsiella $\mathrm{sp}$. is as follows:

Empire : Eukaryota

Kingdom : Chromista 


$$
\begin{array}{ll}
\text { Phylum } & \text { : Dinophyta } \\
\text { Class } & : \text { Dinophyceae } \\
\text { Order } & : \text { Peridiniales } \\
\text { Family } & : \text { Peridiniaceae } \\
\text { Genus } & \text { : Scrippsiella }
\end{array}
$$

The growth of Scrippsiella sp. in culture flasks showed a long logarithmic phase that lasted for 23 days, from day 7 to day 30 (Figure 1 ). The lag phase was not observed in this trial. The highest cell density was reached after 35 days during the onset of stationary phase with 9,097 cells/ mL.

When growth was obtained from fluorescence measurements, Scrippsiella sp. cells showed a long lag phase and a logarithmic phase different from that of cells in the counting experiment, indicating growth restraint due to different culture environment from $\mathrm{f} / 8$ to $\mathrm{f} /$ 2 medium. Also, the difference between surface and volume ratio in flasks and tubes may also contribute to the different growth rate. The logarithmic phase started on day 21 and ended on day 47 (Figure 2). The fourth replicate showed a slower growth compared to the rest of the cultures and therefore was excluded from the growth data.

Simple linear regression analysis of Scrippsiella sp. growth for both experiments during logarithmic phase showed that there is a significant relationship between cell density and culture age (Adjusted R- Squared was 0.93 and 0.99 for fluorometer and counting experiment, respectively with $p$ - value $<0.0001$, Figure 3).

\section{Melosira cf. moniliformis}

The chain- forming diatom species obtained from Kendari Bay was identified as Melosira cf moniliformis. This species was sampled from brackish water of Kendari Bay estuary at temperature of $23^{\circ} \mathrm{C}$ and 5 psu salinity. The taxonomic classification for this species from Guiry (2013) is as follows:
Empire
: Eukaryota
Kingdom : Chromista
Infrakingdom : Heterokonta
Phylum : Ochrophyta
Class : Coscinodiscophyceae
Order : Melosirales
Family : Melosiraceae
Genus : Melosira
Species : M.cf. moniliformis (O F. Müller) C. Agardh 1824

Simple linear regression (SLR) analysis during logarithmic phase showed a strong relationship between culture age and growth of M. cf. moniliformis (Adjusted R- Squared was 0.96 , Figure 6) although without a significant correlation ( $p$ value $=0.09$ )

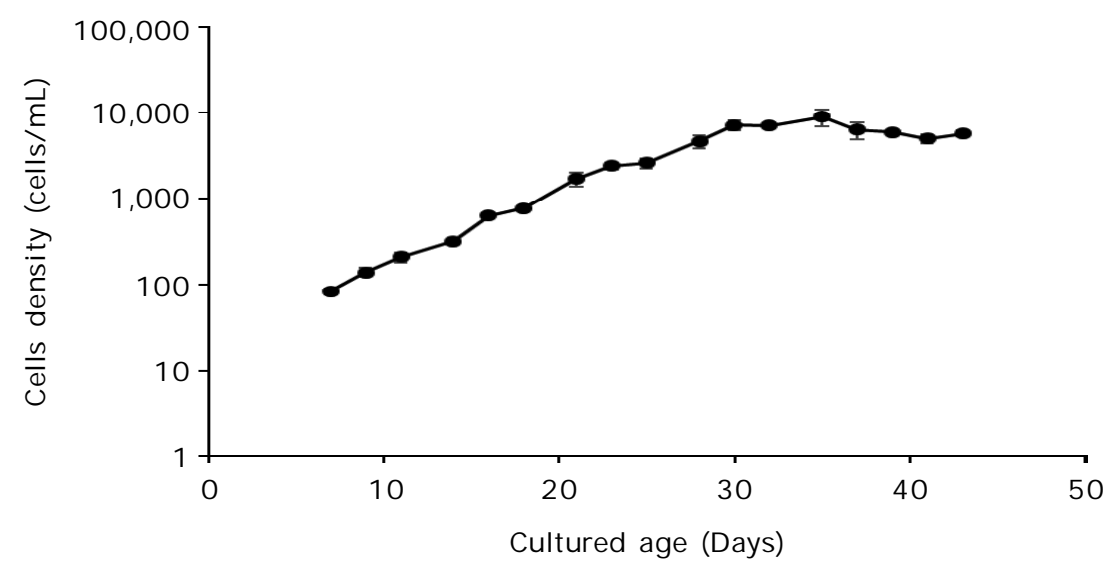

Figure 1. Growth of Scripssiella sp. in culture flasks over a 43- day period. Logarithmic phase started on day 7 and ended on day 30 . The growth rate $(\mu)$ during logarithmic phase was 0.17 day $^{-1}$. Division rate $(k)$ during logarithmic phase was 0.25 day $^{-1}, 1$ division every 4 days $(T)$. The daily cell density is the average of cell counts of the three cultures. Standard errors about the mean are represented by the error bars symbol 


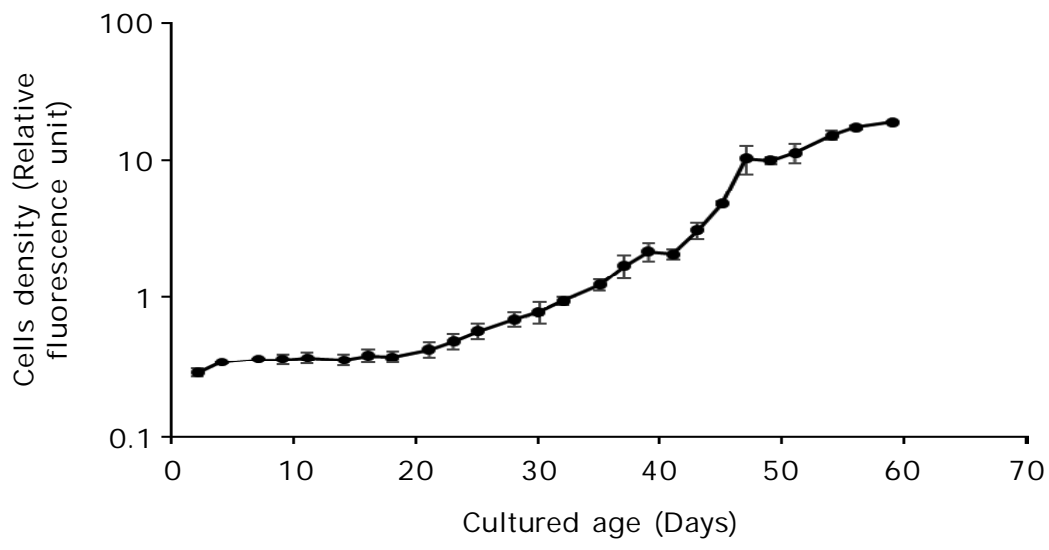

Figure 2. Scrippsiella sp. growth in fluorometer experiment. The logarithmic phase started on day 21 and ended on day 47. Growth rate $(\mu)$ during logarithmic phase was 0.12 day $^{-1}$. Division rate $(k)$ during logarithmic phase was 0.18 day $^{1}, 1$ division every 5.65 days (T). The daily cell density is the average of cell counts in the three cultures. Standard errors about the mean are indicated by error bars
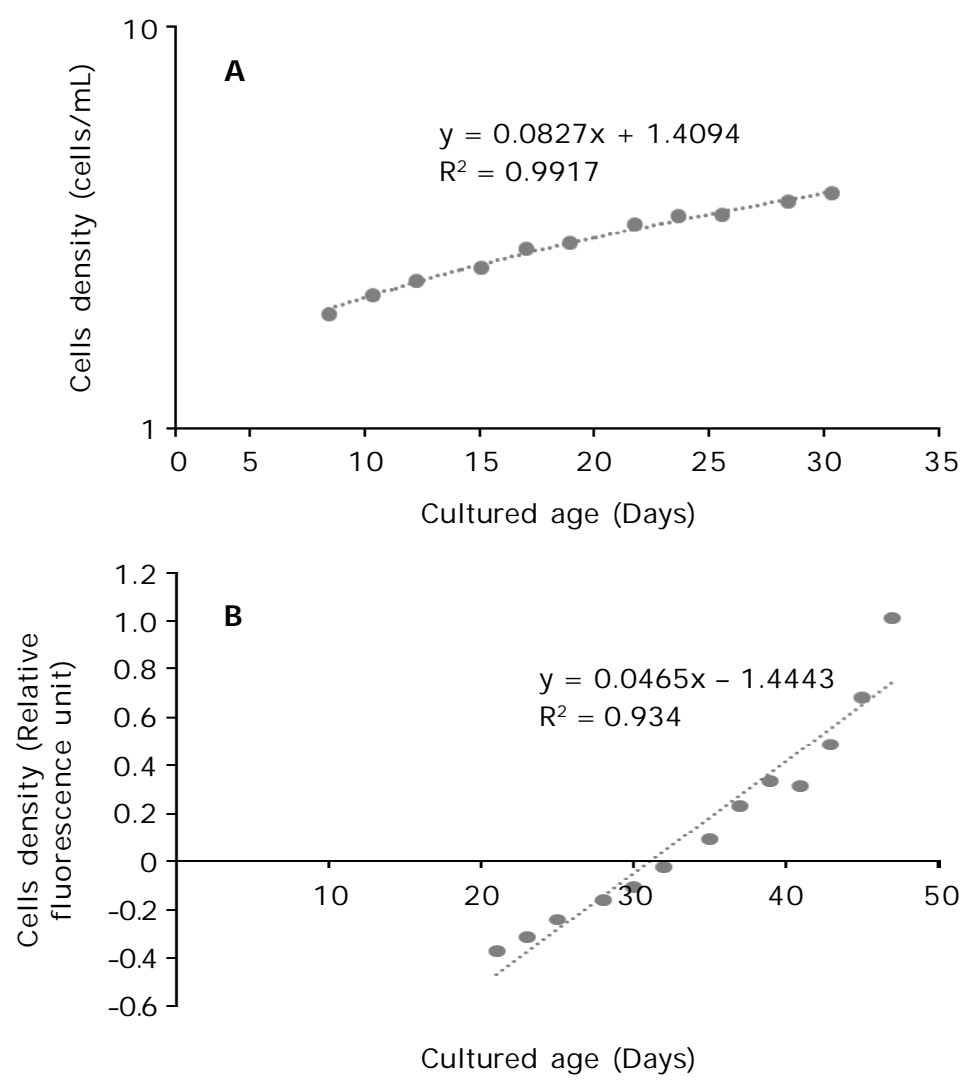

Figure 3. Relationship between culture age and culture density in growth of Scrippsiella sp. cell density on the figures is in $\log , A=$ Counting experiment, $B=$ Fluorometer experiment 


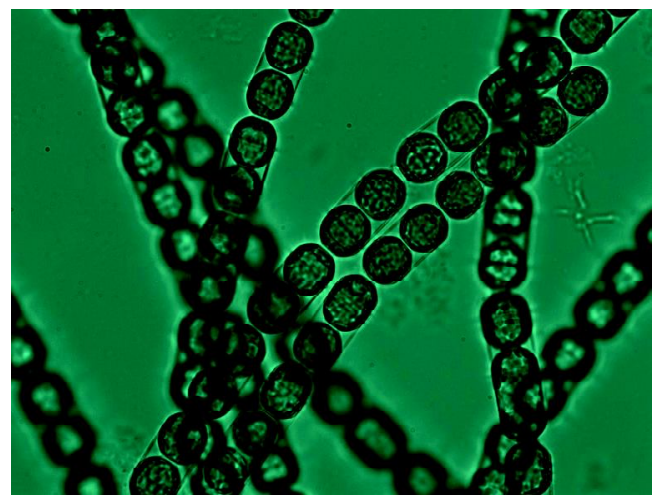

Figure 4. M. cf. moniliformis isolated in this study

\section{DISCUSSION}

The growth curve is an important indicator to determine the growth phase of microalgae cultures. Determining the growth phase is critical for aquaculture nutrition as the nutrition value of microalgae varies between the phases. Several studies found that carbohydrate, protein, lipid, and sterol composition of microalgae were high in late logarithmic phase or at the onset of stationary phase (Mansour et al., 2003; Ponomorenko et al., 2004; MartinezHernandez et al., 2006; Schwenk et al., 2013). The curves obtained in this experiment clearly show different growth patterns between a diatom and a dinoflagellate. The diatom, M. cf. moniliformis grew faster and the cells density

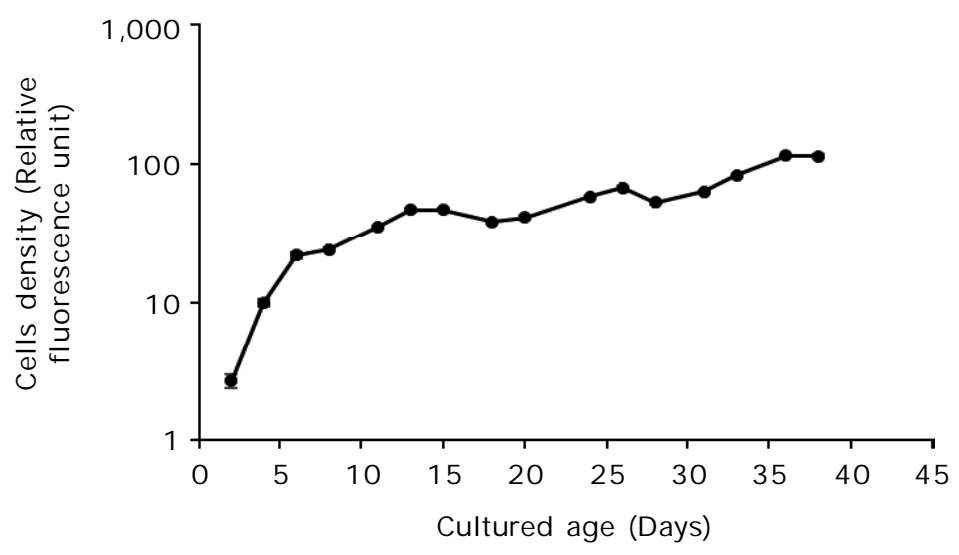

Figure 5. Growth of M. cf. moniliformis. Logarithmic growth phase was between days 2 to $6,\left(\mu=0.52\right.$ day $^{-1}, k=0.76$ day $^{-1}$, 1 division every 1.3 days). Standard errors about the mean of 3 replicates are indicated by error bars symbol

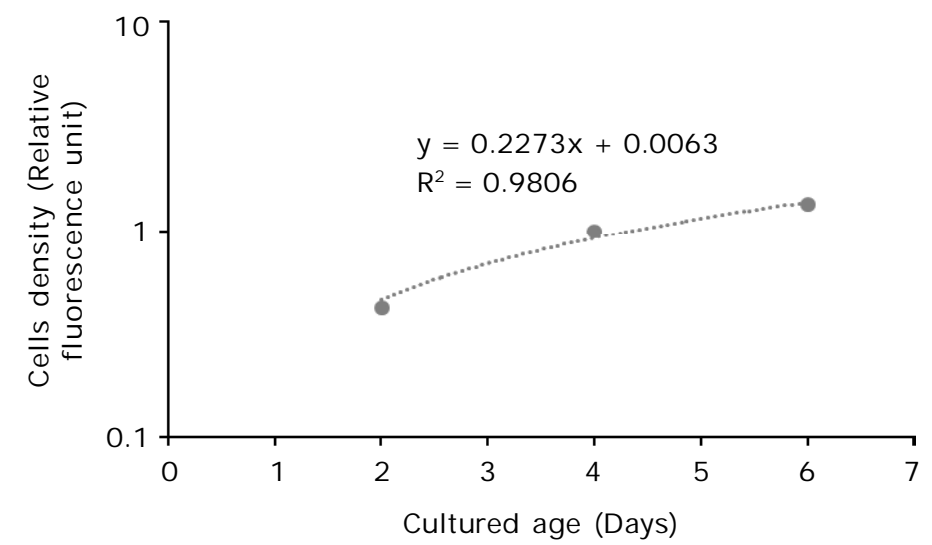

Figure 6. Relationship between cell density and culture age in the growth of M. cf. moniliformis 
was significantly increased as the culture age increased during logarithmic phase. The cells were in logarithmic phase when observed after 2 days of inoculation into the new culture media while Scrippsiella sp. needed 7 days to reach logarithmic phase in culture flasks and 21 days in culture tubes. Species with a high growth rate within a short period are good candidates for aquaculture feeds as this should reduce production and maintenance costs. This study indicates that M. cf. moniliformis can be considered in aquaculture pending further investigations of its nutrition profiles.

Optimum culture conditions are also critical to ensure good growth of microalgae. Temperature, light, and nutrition are some of the main factors that should be monitored carefully during the culture period (Lavens \& Sorgeloos, 1996; Coles \& Jones, 2000). The diatom species in this experiment divided their cells almost every day, indicating the cultures were maintained within their optimum environment. This result confirms numerous data on diatom growth patterns under optimal culture conditions, where their biomass doubles daily (Lavens \& Sorgeloos, 1996; Ponomorenko et al., 2004; Nurachman et al., 2012).

The dinoflagellate species in this experiment showed a slow growth rate that may be due to different culture media used between starter culture and batch culture for growth experiment as well as volume ratio difference between culture vessels. Many dinoflagellates are not used in aquaculture hatcheries feed due to their toxic potentials. Garate- Lizzarraga et al. (2009) suggested that Scrippsiella trochoidea, with a relatively high content of protein, may be a good complement to the diet of shrimp. However, Tang \& Gobler (2012) found that Scrippsiella trochoidea had a lethal effect on Eastern oyster (Crassostrea virginica) and Northern quahog (Mercenaria mercenaria) larvae at a density of $10^{4}$ cells $\mathrm{mL}^{-1}$. Moreover, some dinoflagellates from genus Gymnodinium such as Gymnodinium catenatumis harmful and responsible for paralytic shellfish poisoning (Costa et al., 2010), however, some species from this genus may potentially be used in aquaculture as they contain high lipid and sterol for cultured bivalves and shrimps as studied by Mansour et al. (2003).

Although the diatom isolated in this study came from a warm and low salinity environment, it adjusted very well to the culture conditions. Kendari Bay estuary receives high nutrient in- put from waste water in its surroundings. This may explain the good growth of $\mathrm{M}$. cf. moniliformis isolated from this area. Microalgae species that live in high nutrient environments usually exhibit good growth under laboratory and controlled conditions. Cai et al. (2013), found that several species of microalgae, such as Chorella spp., Scenedesmus sp., Oscillatoria sp., and Isochrysis sp., which are commonly used in aquaculture, tend to grow better in high- nutrient wastewater. This trait is an advantage for aquaculture where species that are robust and easy to culture are needed for mass cultivation and transportation purposes.

\section{CONCLUSION}

M. cf. moniliformis isolated from Kendari Bay showed better growth under similar laboratory culture condition than Scrippsiella sp. Therefore this species can be used for aquaculture hatcheries feed but further study of its nutritional composition is needed. The potential use of Scrippsiella sp. as feed for shrimp hatcheries need to be assessed carefully considering their toxic potentials over nutritionals value.

\section{REFERENCES}

Andersen, R.A. 2011. Algal culturing techniques. Elsevier Academic Press and Phycological Society of America. $578 \mathrm{pp}$.

Attaran- Fariman, G. \& Bolch, C.J.S. 2012. Morphology and phylogeny of Scrippsiella trochoidea (Dinophyceae) a potentially harmful bloom forming species isolated from the sediments of Iran's south coast. Iranian Journal of Fisheries Sciences, 11: 252- 270.

Avila- Villa, L.A., Martínez- Porchas, M., GollasGalván, T., López- Elías. J.A., Mercado, L., Murguia- López, A., Mendoza- Cano, F., \& Hernández-López, J. 2011. Evaluation of different microalgae species and Artemia (Artemia franciscana) as possible vectors of necrotizing hepatopancreatitis bacteria. Aquaculture, 318: 273- 276.

Cai, T., Park, S.Y., \& Li, Y. 2013. Nutrient recovery from waste water streams by microalgae: Status and prospects. Renewable and Sustainable Energy Reviews. 19: 360369.

Carboni, S., Vignier, J., Chiantore, M., Tocher, D.R., \& Migaud, H. 2012. Effects of dietary microalgae on growth, survival, and fatty acid composition of sea urchin Paracen- 
trotus lividus throughout larval development. Aquaculture, 324- 325: 250- 258.

Costa, P.R., Botelho, M.J., \&Lefebvre, K.A. 2010. Characterization of paralytic shellfish toxins in seawater and sardines (Sardinapil chardus) during blooms of Gymnodinium catenatum. Hydrobiologia, 655: 89- 97.

Edwards-Jones, G. 2010. Does eating local food reduce the environmental impact of food production and enhance consumer health?. Symposium on 'Food supply and quality in a climate- changed world'. Proceedings of the Nutrition Society, 69: 582- 591.

Galardo, P.P., Pedroza- Islas, R., Garcia- Galano, T., Pascual, T., Rosal, C., Sanchez, A., \& Gaxiola, G. 2002. Replacement of live food with micro bound diet in feeding Litopaneus setiferus (Burkenroad) larvae. Aquaculture Research, 33: 681- 691.

Gárate- Lizárraga, I., Band- Schmidt, J.B., LópezCortés, D.J., \& Muñetón- Gómez, M.S. 2009. Bloom of Scrippsiella trochoidea (Gonyaulacaceae) in a shrimp pond in the Southwestern Gulf of California, Mexico. Marine Pollution Bulletin, 58: 145- 149.

Guiry, M.D. \& Guiry, G.M. 2013. Algae Base. World- wide electronic publication, National University of Ireland, Galway. http:// www.algaebase.org; searched on 04 December 2013.

Hasle, G.R., Syversten, E.E., Steidinger, K.A., Tangen, K., Throndsen, J., \& Heimdel, B.R. 1997. Identifying marine phytoplankton. Academic Press. San Diego. USA, 858 pp.

Horner, R.A. 2002. A taxonomic guide to some common phytoplankton. Biopress Limited, Dorset Press, Dorchester. UK, 200 pp.

Kent, M., Browdy, C.L., \&Leffler, J.W. 2011. Consumption and digestion of suspended microbes by juvenile Pacific white shrimp Litopenaeus vannamei. Aquaculture, 319: 363- 368.

Kröger, N., Deutzmann, R., \& Sumper, M. 1999. Polycationic peptides from diatom biosilica that direct silica nanosphere formation. Science, 286: 1,129- 1,132.

Lavans, B. \& Sorgeloos, B. 1996. Manual on the production and use of live food for aquaculture. FAO Fisheries Tech paper 1996.

Ma, Z. \& Qin, J.G. 2012. Replacement of fresh algae with commercial formulas to enrich rotifers in larval rearing of yellow tail kingfish Seriola lalandi (Valenciennes, 1833). Aquaculture Research, p. 1- 12.

Majewska, R., Zgrundo, A., Lemke, P., \& De
Stefano, M. 2012. Benthic diatoms of the Vistula River estuary (Northern Poland): Seasonality, substrata preferences, and the influence of water chemistry. Phycological Research, 60: 1- 19.

Martínez- Fernández, E., Acosta- Salmón, H., \& Southgate, P.C. 2006. The nutritional value of seven species of tropical microalgae for black- lip pearl oyster (Pinctada margaritifer a L.) larvae. Aquaculture, 257: 491- 503.

Martínez- Fernández, E. \& Southgate, P.C. 2007. Use of tropical microalgae as food for larvae of the black- lip pearl oyster Pinctada margaritifera. Aquaculture, 263: 220- 226.

Nurachman, Z., Brataningtyas, D.S., Hartati, \& Panggabean, L.M.G. 2012. Oil from the tropical marine benthic- diatom Navicula sp. Appl. Biochem. Biotechnol., 168: 1,065- 1,075.

Rohani- Ghadikolaei, K., Ng, W.K., Abdulalian, E., Naser, A., \& Yusuf, A. 2012. The effect of seaweed extracts, as a supplement or alternative culture medium, on the growth rate and biochemical composition of the microalga, Isochrysis galbana (Park 1949). Aquaculture Research, 43: 1,487- 1,498.

Ponomarenko, L.P., Stonik, I.V., Aizdaicher, N.A., Orlova, T.Y., Popovskaya, G.I., Pomazkina, G.V., \&Stonik, V.A. 2004. Sterols of marine microalgae Pyramimonas Cf. Cordata (Prasinophyta), Attheya ussurensis sp. Nov. (Bacillariophyta) and a spring diatom bloom from Lake Baikal. Comparative Biochemistry and Physiology Part B, 138: 65- 70.

Sanchez, D.R., Fox, J.M., Gatlin III, R., \& Lawrence, A.L. 2012. Dietary effect of fish oil and soybean lecithin on growth and survival of juvenile Litopenaeus vannamei in the presence or absence of phytoplankton in an indoor system. Aquaculture Research, p. 1- 13.

Schwenk, D., Seppala, J., Spilling, K., Virkki, A., Tamminen, T., Oksman- Caldentey, K.M., \& Rischer, H. 2013. Lipid content in 19 brackish and marine microalgae influence of growth phase, salinity and temperature. Aquat. Ecol., 47: 415- 424.

Sumper, M. \& Brunner, E. 2006. Learning from diatoms: nature's tools for the production of Nanostructured Silica. Adv. Funct. Mater., 16: 17- 26.

Taelman, S.E., De Meester, S., Roef, L., Michiels, M., \& Dewulf, J. 2013. The environmental sustainability of microalgae as feed for aquaculture: A life cycle perspective. Bioresource Technology. Article in Press. 
Isolation and growth of dinoflagellate, Scrippsiella sp.... (Wa Iba)

Tang, Y.Z. \& Gobler, C.J. 2012. Lethal effects of Northwest Atlantic Ocean isolates of the dinoflagellate, Scrippsiella trochoidea, on Eastern oyster (Crassostrea virginica) and Northern quahog (Mercenaria mercenaria) larvae. Mar. Biol., 159: 199- 210.

Wikfors, G.H. \& Ohno, M. 2001. Impact of algal research in aquaculture. J. Phycology, 37: 968- 974.
Wood, A.M., Everroad, A.C., \& Wingard, L.M. 2005. Measuring growth rate in microalgal cultures. In Andersen, R.A. (Ed.). Algal Culturing Techniques. Elsevier Academic Press and Phycological Society of America. $578 \mathrm{pp}$. 